\title{
Implementation and Effectiveness of Local Ordinances on Legal Aid to Secure Justice for Marginalized Community in Indonesia
}

\author{
Heru Susetyo ${ }^{1}$, Farida Prihatini ${ }^{2}$, Gemala Dewi $^{3}$, Andini Naulina Rahajeng ${ }^{4}$, Nur Alim \\ Arrazaq $^{5}$, Ainunnisa Rezky Asokawati ${ }^{6}$ \\ \{andini.naulina@ui.ac.id $\left.{ }^{4}\right\}$
}

Faculty of Law, University of Indonesia, Depok, Indonesia ${ }^{1,2,3,5,6}$

\begin{abstract}
Local Ordinances about Legal Aid is a follow-up of Law Number 16 of 2011 about Legal Aid. Legal aid for the marginalized community is a way to protect access to justice for all citizens. It is caused by the financial gap to fulfill the needs of advocates when facing legal issues. So, the government provides free legal aid to the marginalized communities that can not afford it. This local ordinance is an implementation of the 1945 Constitution of the Republic of Indonesia and part of Sustainable Development Goals (SDGs) point 16. This research will identify, evaluate, and review the implementation and effectiveness of local ordinance on legal aid in several regionals that already have the ordinances, such as the City of Padang, Tasikmalaya, Purbalingga, and Yogyakarta. This research employs normative comparative methods with a qualitative approach. It finds that there are a small number of local ordinances about it. In some regions, the regulation itself does not impact society due to limited budget availability and the number of legal aid advocates. The implication is that local ordinances on legal aid should and must secure access to justice for marginalized communities.
\end{abstract}

Keywords: Local ordinances, legal aid, marginal communities

\section{Introduction}

Legal aid appears as a cause of Indonesia's obligation for it, so it should provide the marginal communities with legal assistance from the first stage of the investigation until the judges give permanent legal force in the court. Not all citizens can provide it due the financial gap. Legal aid is one of the proofs that Indonesia, as a nation of law, protects all citizens' layers, including the marginal communities. Justice for marginal communities at the law in Indonesia ruled in the Constitution Article 27 paragraph (1) in conjunction with Article 34 paragraph (1) [1]. Also, point 16 of Sustainable Development Goals (SDGs) leads to having justice for all. In 2011, Indonesia made Law Number 16 the Year 2011 on Legal Aid to specify legal aid regulation. Article 19 paragraph (2) is embodied as local ordinances in regionals [2]. As a result, every province could also make their own local ordinances regarding their own needs about legal aid be guided by Law on Legal Aid. Although they have regional autonomy to make it, not every regional, provide it. So, the legal aid for every marginal community is still not distributed evenly.

As the Law on Legal Aid 2011 delegate regionals to make their own local ordinance, the Government gives budget allocation on legal aid to legal aid organizations for adequate the 
citizens need on law based on government organizations or the independences. For example, the Indonesian Advocacy Center for Law and Human Rights (PAHAM) also have Pos Bantuan Hukum. There are already some journals of legal aid in Indonesia, but there are several papers in international journals about the implementation of legal aid in Indonesia.

This paper will discuss the implementation and effectiveness of legal aid in several regionals in Indonesia. The research will focus on implementing several regional local ordinances on Legal Aid, such as the City of Padang, Tasikmalaya, Yogyakarta, and Purbalingga. It also compares how legal aid is fulfilled by legal aid organizations like PAHAM, the Indonesian Legal Aid Foundation (YLBHI), and Legal Aid Agency in Yogyakarta (LBH Yogyakarta). This paper aims to compare the implementation of legal aid in Indonesia through local ordinances on legal aid.

\section{Method}

This research method is narrative with a qualitative approach data obtained through literature studies and interviews. The literature study used consists of primary and secondary legal materials. Primary legal material consists of Law Number 16 the Year 2011 on Legal Aid, Government Regulation No. 43 of 2013 concerning Terms and Procedures for Providing Legal Assistance and Distribution of Legal Aid Funds, as well as regional regulations for legal aid in each region (City of Purbalingga, Tasikmalaya, Yogyakarta, and Padang).

The secondary legal material includes all legal publications on legal aid, particularly regarding the effectiveness of local regulations on legal aid in several areas where this research is conducted. Previously, almost similar research had been carried out regarding legal aid, one of which was the research of Angga and Ridwan Arifin entitled "The Application of Legal Aid for Underprivileged People in Indonesia," published in Journal of Diversion Law Volume 4 the year 2018. This study only examined the provision of legal aid to the marginalized community. Still, only general discussion in Indonesia, there is no explanation regarding the regulation made by the regions in applying legal aid. Then there is also similar research in the legal research journal by Budijanto in 2016 with the title of Increasing Access to Legal Aid For The Poor. The shortcomings of this study do not explain the effectiveness of regional regulations that govern this legal aid.

\section{Result and Discussion}

\subsection{Results}

\subsubsection{Purbalingga}

Regulation related to Legal Aid in the Purbalingga Regency is regulated by Local Ordinance Number 1 of 2017 concerning Legal Aid for the Poor. Like the previous regulation, the provision of legal assistance is provided to the poor with an identity in the form of an Identity Card / Family Card domiciled in Purbalingga Regency. A Poor Certificate confirms this from the Village or Sub-District. The poor's definition in this regulation is a society that cannot meet their basic needs such as clothing, food, shelter, education, and health with minimum standards. 
Legal assistance in litigation is provided to defendants, convicted persons who submit ordinary or extraordinary legal remedies, and suspects who are categorized as poor. Legal assistance is provided at the stages of the investigation, prosecution, and legal remedies. For civil cases, legal assistance is provided to the Petitioner / Plaintiff and Defendant / Respondent. Non-litigation legal assistance is provided by paralegals, advocates, lecturers, and law faculty students who meet the requirements. Furthermore, non-litigation legal assistance is regulated in the Purbalingga Regent Regulation. However, until now, there has been no further regulation.

The procedure for filing legal aid according to this perda is the same as the two previous regional regulations. The party whom applying for legal aid, must attach a photocopy of their resident ID Card) or Family Card along with Poor Certificate (reference letter from local authority which explain the degree of poverty of the holder) and also a written description of legal issues to the legal aid provider. Applications can be submitted by potential beneficiaries or their families, either individually or in groups. If the requirements are incomplete, then five days are given to complete it. If it is complete, then the legal aid provider must accept or reject answers within three working days. A maximum of 14 days after the case has been completed or has entered into legal force, the legal aid provider must report to the Regent through the legal department. Funding requests will be reviewed and verified by the Legal Department [3]. Reports are submitted together with payment requests made through a reimbursement mechanism. Payments are made in stages. Provision of legal aid funds is supervised by a Supervisory Team appointed by the Regent. In contrast to the City of Tasikmalaya, whose supervision is carried out by the mayor once a year or as needed.

\subsubsection{Tasikmalaya}

In Tasikmalaya, there is a regional regulation or local ordinance (PERDA) regarding the implementation of legal aid for the poor, namely PERDA number 1 of 2018. This PERDA is a way to protect the principle "equality before the law", which is implemented by allocating a legal aid budget, especially for the poor. Organizing legal aid and allocating legal aid budgets for the poor is an authority and also the responsibility of the central government, as regulated in article 6 paragraph (2) and Article 17 of Law number 16 of 2011 concerning legal aid, as well as article 18 paragraph (1) Government regulation number 42 of 2013 concerning Terms and Procedures for Providing Legal Assistance and Distribution of Legal Aid Funds.

Based on the statistics made by Badan Pusat Statistik data in 2014, the number of legal aid providers in Tasikmalaya Regency is still unequal when compared to the total population. Of the total Kabupaten Tasikmalaya population around 1.7 million, there are only 20 advocates who are active as legal aid providers. So, it can be said that one advocate seems to be accompanying 85,000 residents in Tasikmalaya Regency. There are various problems in building legal awareness and expanding access to legal aid for vulnerable and marginalized communities in the Tasikmalaya Regency, one of which is the unequal number of legal justice seekers and legal aid service providers. With such a long number, it is natural that legal awareness in Tasikmalaya is still low.

On November 7, 2018, a National Paralegal Gathering event was held, initiated by The Asia Foundation and USAID, along with implementing partner institutions such as YLBHI, Peradi, and LBH throughout Indonesia several community organizations communities. The National Paralegal Meeting featured speakers from MAJU (Empowering Access To Justice), the National Law Development Agency (BPHN). This activity is a follow-up to the implementation of Permenkumham (Regulation of Minister of Law and Human Rights) Number 1 in 2018 concerning Paralegals in Providing Legal Aid. Present at the event, representatives from 
USAID, Asia Foundation YLBHI. LBH Jakarta, LBH Bandung, LBH Yogya, LBH Surabaya, Semarang. ALDP and LBH Papua, DPC PERADI Tasikmalaya, Rifka Anisa from Yogya Yapika, LBH Masyarakat LBH Apip Jkt, MAPPI FH UI. Swara Kita, Gwl Ina, Forum for providing services for women victims of violence.

\subsubsection{Yogyakarta}

The city of Yogyakarta has a Local Ordinance on Legal Aid No. 3 of 2019. District Court of Yogyakarta having relation with Association of Indonesian Advocate (PERADI) Yogyakarta already provided 70 issues for the legal aid in 2019. This legal aid has been performed for the marginal communities by Legal Aid Institution District Court of Yogyakarta. From 48 million rupiahs for the implementation of legal aid, the spent are about 47 million. It contains giving advice, legal assistance in court, etc.[4, p. 38].

Mr. Wawan Andriyanto from PAHAM Yogyakarta on the interview said that the implementation of legal aid in Yogyakarta still not effective. The first problem in PAHAM is the human resource. There are only four advocates to handle a lot of cases from the marginalized community. So, they must be selective to take the case. Another problem is the budget for legal aid. Legal aid needs more than legal aid budget allocation. The budget allocation cannot cover all the needs.

While they should take it as part of their work responsibilities as advocates, they also need to do pro bono or give free legal aid to marginalized communities. With the limited source of advocate, they should be selective in the cases. They need to select the most needed people to get legal aid from them. The last problem is the power of regional politics affected the marginalized people. They tend to think that every selected problem that has advocates will free them from jail or penalty. So, the politician pushes the advocates to make the people free from cases.

Based on Annual Report of Indonesian Ministry of Law and Human Rights Year 2013, Kulonprogo is the only regional in Yogyakarta Province that do not have any legal aid agency [5, p. 56]. The limited amount of legal aid organizations in Yogyakarta do affect their working area, like Legal Aid Agency in Yogyakarta which should cover large area, such as Cilacap, Solo, Probolinggo, and some other areas near Yogyakarta [6, p. 15].

\subsubsection{Padang}

The West Sumatra Provincial Government has initiated a policy of providing free legal aid for the poor based on West Sumatra Regional Regulation Number 13 of 2014 concerning the Implementation of Legal Aid. West Sumatra Regional Regulation Number 13 of 2014 concerning the Delivery of Legal Aid is a policy at the provincial level of West Sumatra. As for Padang's city level, the regulation regarding legal aid is regulated in Padang Local Ordinance Number 2 Year 2015 concerning legal aid for the poor [7].

Padang City is the capital of West Sumatra Province, located on the west coast of Sumatra. The area of Padang City is $694.96 \mathrm{~km} 2$ or equivalent to 1.65 percent of West Sumatra Province [8]. Because of Padang City is the capital of West Sumatra Province, it makes all forms of economic, educational, and social activities centered in the city. It not infrequently also raises various kinds of legal problems that arise in the community. One of the well-known legal aid organizations or organizations in Padang is the Center for Legal Advocacy and Human Rights (PAHAM). PAHAM is a national legal aid organization with many branch offices in several cities in Indonesia. one of them is in Padang. The PAHAM office in Padang itself was 
established in 2001. This is the vision of PAHAM itself, namely that justice belongs to all community members without the slightest distinction [9].

The problems encountered by PAHAM West Sumatra in implementing legal aid consisted of internal and external factors. From internal factors, the problem is the lack of resources owned by PAHAM. The facilities are very minimal, especially the absence of office transportation equipment, making it difficult for advocates to mobilize. Meanwhile, many clients are not open and dishonest; besides that, there is a lack of budget to solve a case that requires legal assistance. Case handling operational costs is one of the obstacles to implementing Legal Aid. The cost of 5 million rupiahs per case in the Legal Aid scheme is considered insufficient, especially regarding geographical factors. For Padang's city, the court fee for criminal cases is required as much as 4.7 million to 17.3 million Rupiah. Meanwhile, for civil cases, as much as 6.5 million is needed to 10.5 million Rupiah. Likewise, with the state administration case, a court fee of 6.5 million Rupiah is required. If you look at the Needs Mapping above, then the cost of 5 million rupiahs per case can be relatively sufficient if the case is in the city. Still, if the client is outside the city, it is relatively insufficient [5].

\subsection{Comparison of research objects}

The implementation of legal aid in Purbalingga is generally carried out by three agencies, namely: first legal aid institutions such as PAHAM, LBH. Then also go to the Posbakum Court. The latter can go directly to the local government law firm so they can find a free lawyer. The village government in Tasikmalaya Regency continues to strive to improve legal understanding for the community. At least 20 villages have pressed the Memorandum of Understanding (MoU) to increase legal understanding and legal assistance with the ANSOR Legal Aid Institute (LBH). From the records of LBH ANSOR, at least 20 villages in three sub-districts have made MoUs. However, understanding of the law at the village government level is still minimal. Following this MoU, a legal aid post was opened at the village level. The community can also be consulted in case of legal proceedings.

Indonesian Legal Aid Foundation Yogyakarta (LBH), from their annual report year 2019, found several issues for legal aid provided in 2019: land and environment issues, a community of religions and beliefs issues, etc. LBH Yogyakarta in 2019 provided legal aid for 200 issues with 8.567 beneficiaries. In Padang City, legal aid is provided to underprivileged people facing legal problems. The problem is related to civil law, criminal law, state administrative law, both in litigation and non-litigation. Legal aid implementation is carried out by a legal aid agency that has met the requirements stipulated in this Padang city regional regulation. There are five legal aid agencies in Padang City, such as PAHAM, LBH, and others.

\section{Conclusion}

The right to legal aid has been universally accepted, as guaranteed in the International Covenant on Civil and Political Rights (ICCPR) which has been ratified by Indonesia through Law No. 12/ 2005. In the rule of law, the state recognizes and protects human rights for every individual, including the right to legal aid. In all four object places, legal aid is regulated. In Purbalingga, the legal aid is carried by three agencies as the implementation. In Tasikmalaya, it's implemented by MoUs. In Yogyakarta, there are several fields of issues for legal aid provided. In Padang, there are five legal aid agencies. But, the implementation of regional 
regulation needs to be more comprehensive and cover local people's needs. So, it can be applied more effectively.

\section{Acknowledgment}

This paper is derived from the research financed by Universitas of Indonesia Research Grant 2020 under PUTI Scheme.

\section{References}

[1] Indonesia, "The 1945 Constitution of the Republic of Indonesia," 1945.

[2] Indonesia, Indonesian Law Number 16 Year 2011. Indonesia, 2011, pp. 1-21.

[3] Central Java Provincial Government, "Purbalingga Regency Government Prepares Legal Aid for the Poor," 2020. [Online]. Available: https://jatengprov.go.id/beritadaerah/pemkab-purbalinggasiapkan-bantuan-hukum-untuk-masyarakat-miskin/. [Accessed: 10-Nov-2020].

[4] Pengadilan Negeri Yogyakarta, "Laporan Pelaksanaan Kegiatan Tahun 2019," Yogyakarta, 2019.

[5] Indonesian Ministry of Law and Human Rights, "Laporan Tahunan Implementasi Undang-Undang Nomor 16 Tahun 2011 tentang Bantuan Hukum," Jakarta, 2013.

[6] Yogyakarta Legal Aid Agency, "Investasi Subur Rakyat Digusur: Catatan Akhir Tahun LBH Yogyakarta 2019," Yogyakarta, 2019.

[7] Padang City, Padang City Local Ordinance Number 2 Year 2015 of Legal Aid for Poor People. Indonesia, 2015.

[8] Wikipedia, "Padang." [Online]. Available: https://en.wikipedia.org/wiki/Padang. [Accessed: 10Nov-2020].

[9] T. Aklima, "Implementation of Legal Aid for The Accused by Pusat Advokasi Hukum dan HAM (PAHAM) in West Sumatera," University of Andalas, 2018. 